\title{
Technology of Luster Glaze Enamel Production, Based on the Formula in the Book of "Jawāher-nāma-ye Neẓāmi"
}

\author{
M. MIR-SHAFIEI ${ }^{\mathrm{a}^{*}}$, and M. MOHAMMADZADEH ${ }^{\mathrm{b}}$ \\ a Instructor and faculty member of Tabriz Islamic Art University, Tabriz, IRAN \\ b Assistant professor of Tabriz Islamic Art University, Tabriz, IRAN
}

\begin{abstract}
The enamel painting has a long history in Iran. However, this is a lost art and few glass artists are interested in enameling. The oldest traces of Zarrin Faam performed on glass containers were found in Egypt in the second century AH. Since then, this technique was used on glazed pottery at the Islamic era. Zarrin Faam, a thin layer of copper and silver nanoparticles, is an enamel in which luster glaze is used in painting and decorating on the glaze which is heated in reduced kiln as the third step. There are two historical literature about technology and composition of luster glazes:

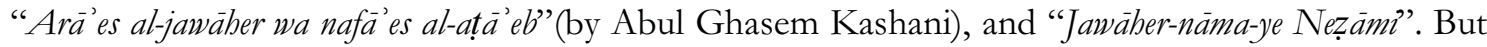
the only book that explains art of enameling on glass is the second one by "Mohammad Ibn al Barakat Neishabouri" written in 595 AH. The author has indicated the formulas for crystal enameling. In this research, two formulas of this book has been explained and, it was tried to adopt an experimental approach to introduce and recognize the art of lusterware enamel. Afterwards, technique of glass Meenakari or enameling was practiced. The chemical composition of this layer was investigated using scanning optical microscope, and the results suggested that vitreous Zarrin Faam enamel can be made in accordance with the formulas mentioned in the book, and under reduction conditions. It was found that type of glass, Mina compound or formula, and reduction condition are among the factors influencing the formation of lusterware layers. It is noteworthy that reduction firing includes several variables such as firing time, temperature, and fumigation intensity. It could be concluded that making lusterware at the proper way can be achieved by choosing the appropriate factors mentioned.
\end{abstract}

Keywords: Vitreous Zarrin Faam eamel, Jawaher-name-ye Nizami, Luster glaze, Reduction firing.

* _ Corresponding author: mohamadmirshafiei@tabriziau.ac.ir 


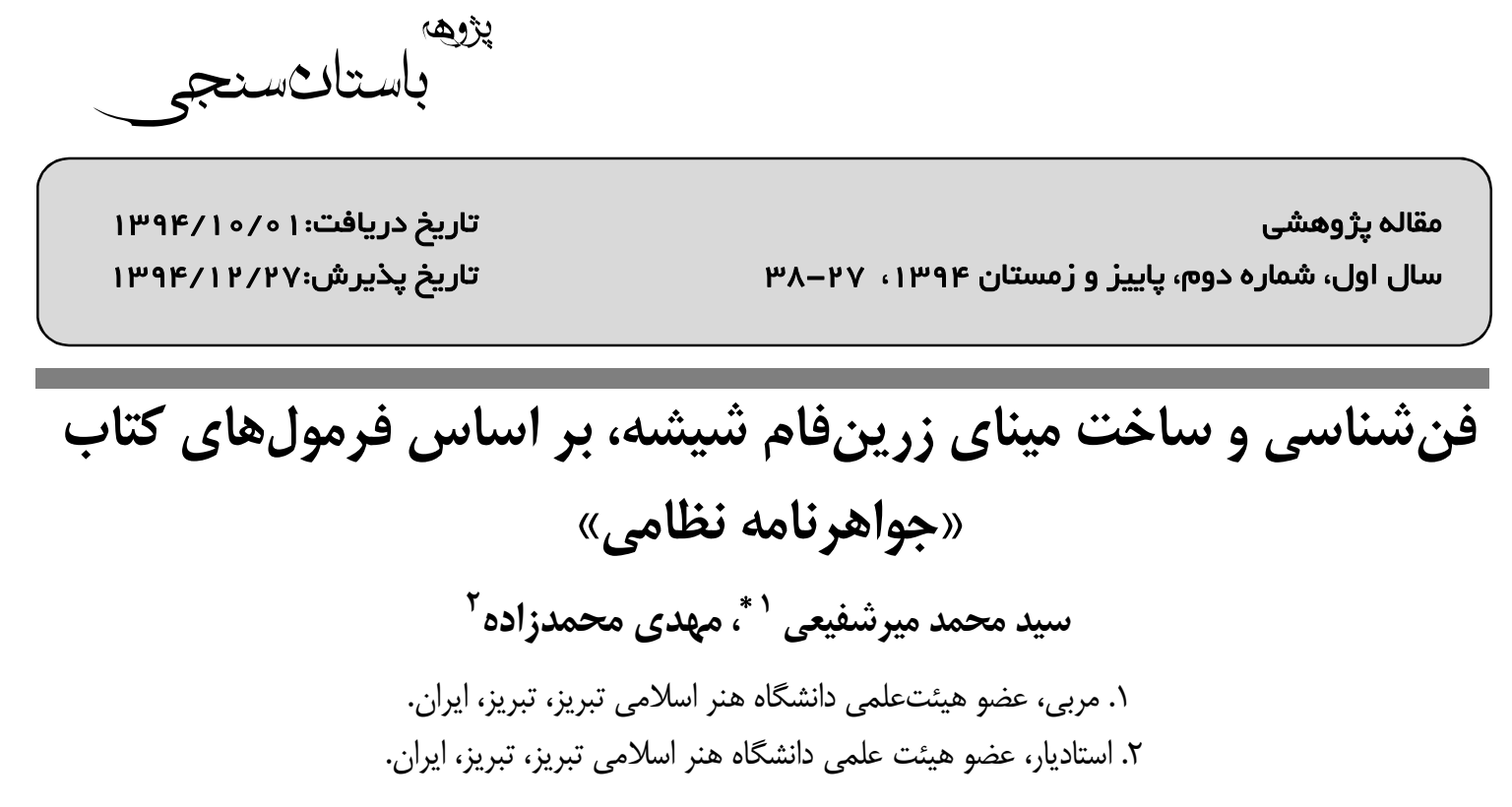

جكيده

نخستين آثارى كه از شيوه زرينفام بهدست آمده متعلق به مصر و سده دوم ه.ق است كه بر روى ظروف شيشهاى اجرا شده است. ايـن

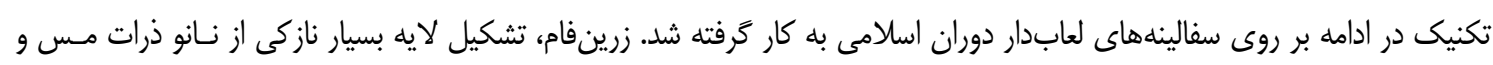

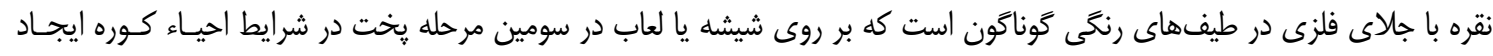

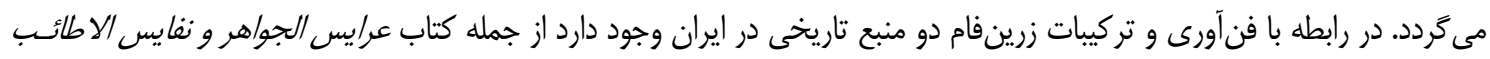

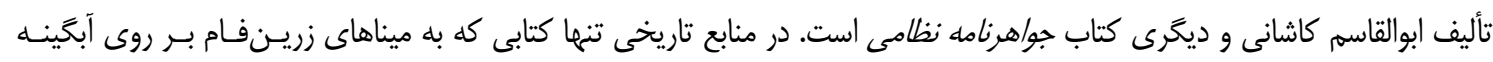

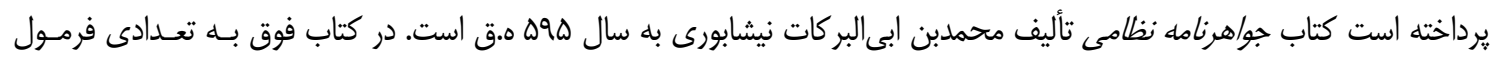

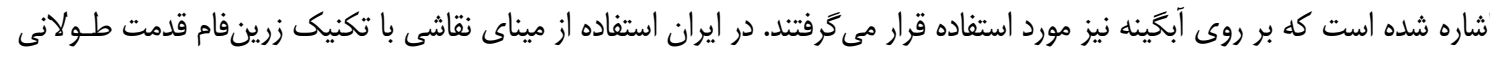

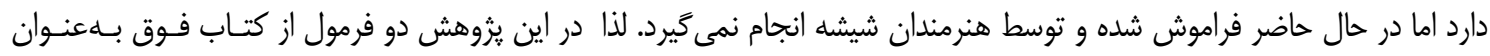

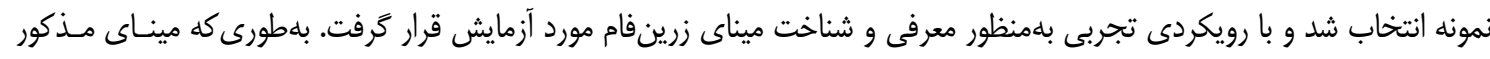

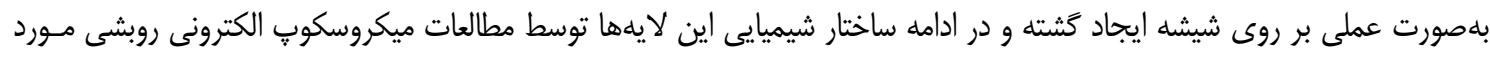

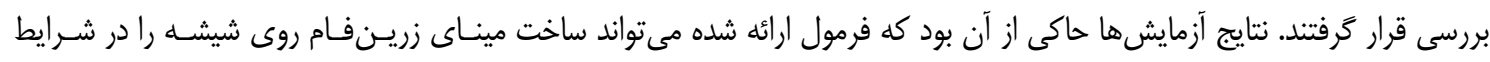

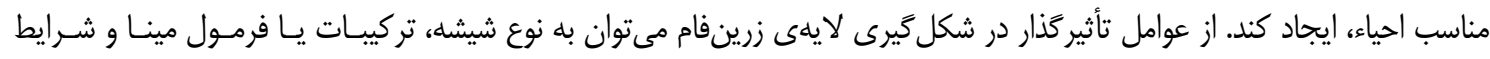

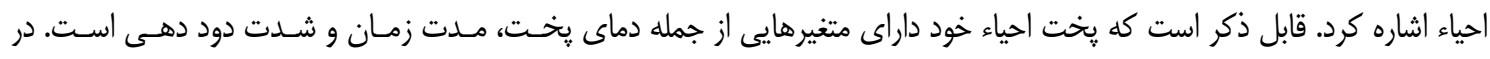

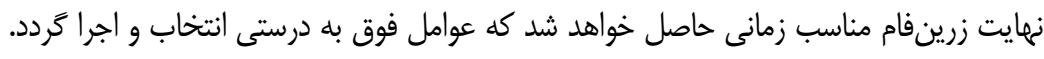

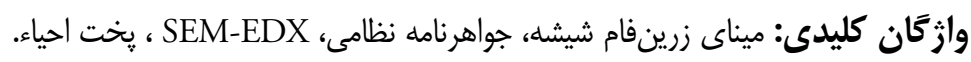

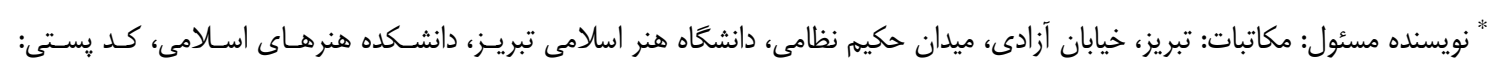

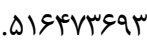
mohamadmirshafiei@tabriziau.ac.ir :حست الكترونى C) حق نشر متعلق به نويسنده(ًان) است و نويسنده تحت مجوز Creative Commons Attribution License به مجله اجازه مىدهد مقاله خاب شده را با ديخران به اشتراك بخذارد منوط بر اينكه حقوق مؤلف اثر حفظ و به انتشار انتشار اوليه مقاله در اين مجله اشاره شود. 
بحث ييرامون شناخت ميناى زرينفام و كتاب جواهرنامه

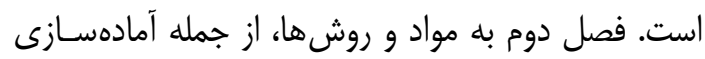

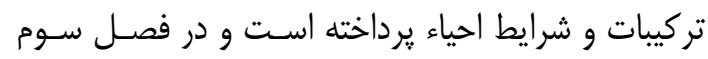

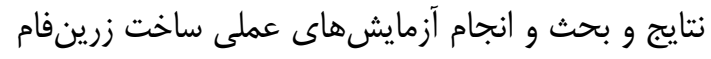

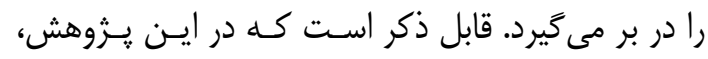

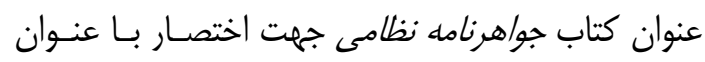

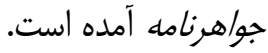

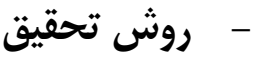

اين تحقيق از نوع تحقيقات كاربردى است. دادهاديق اوليه

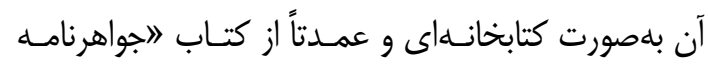

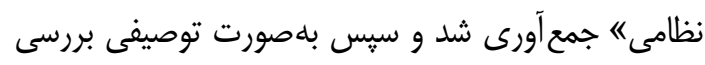

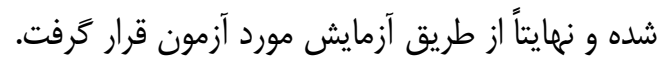

\section{- - بيشينه تحقيق}

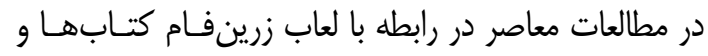

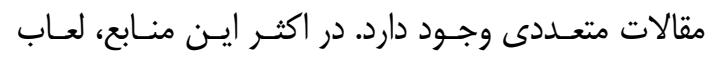

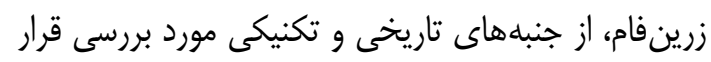

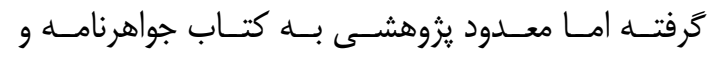

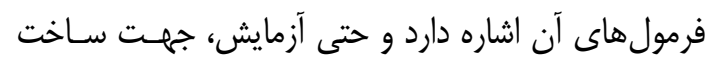

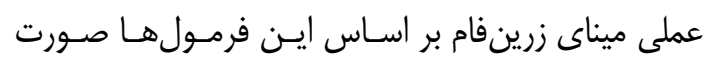

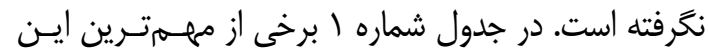
يزوهشها آمده است.
باستانسنتجى

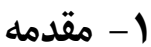

ميناى زرينفام از جمله موضوعاتى است كه همـواره بـــــ

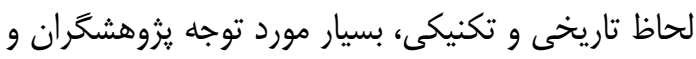
هنرمندان سفالكر قرار كرفته است. فنون و شيوه سـاخت لعاب زرينفام در طول تاريخ اجراى آن در اختيـار افراد

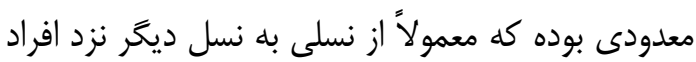

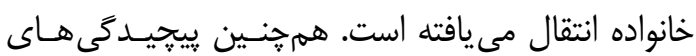
ساخت لعاب زرينفام موجب شده تا اين تكنيك به امرى

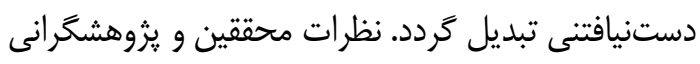

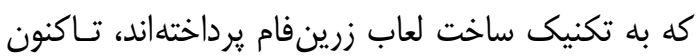
معطوف به دو كتاب تاريخى در اين زمينه يعنى عـرايس

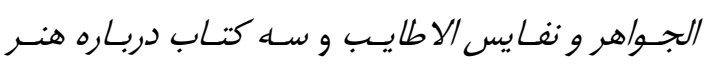

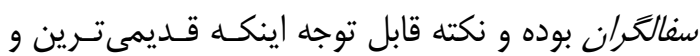
مفصلترين منبع تاريخى در مورد ميناهاى زرينفام يعنى

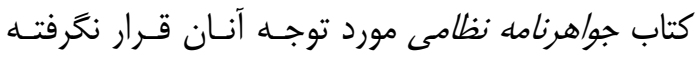

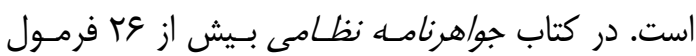

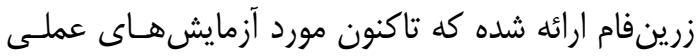
واقع نشده است. در كتاب فوق تعدادى فرمول وجود دارد اردارد

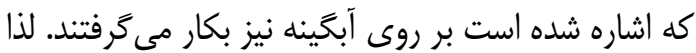

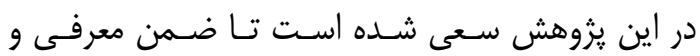

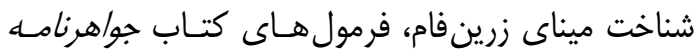

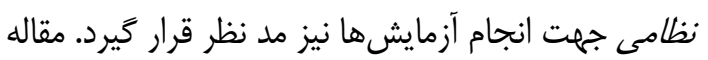
شامل سه فصل است كـه فصـل اول كليـات تحقيـق و

$$
\text { جدول (: ييشينه تحقيق }
$$

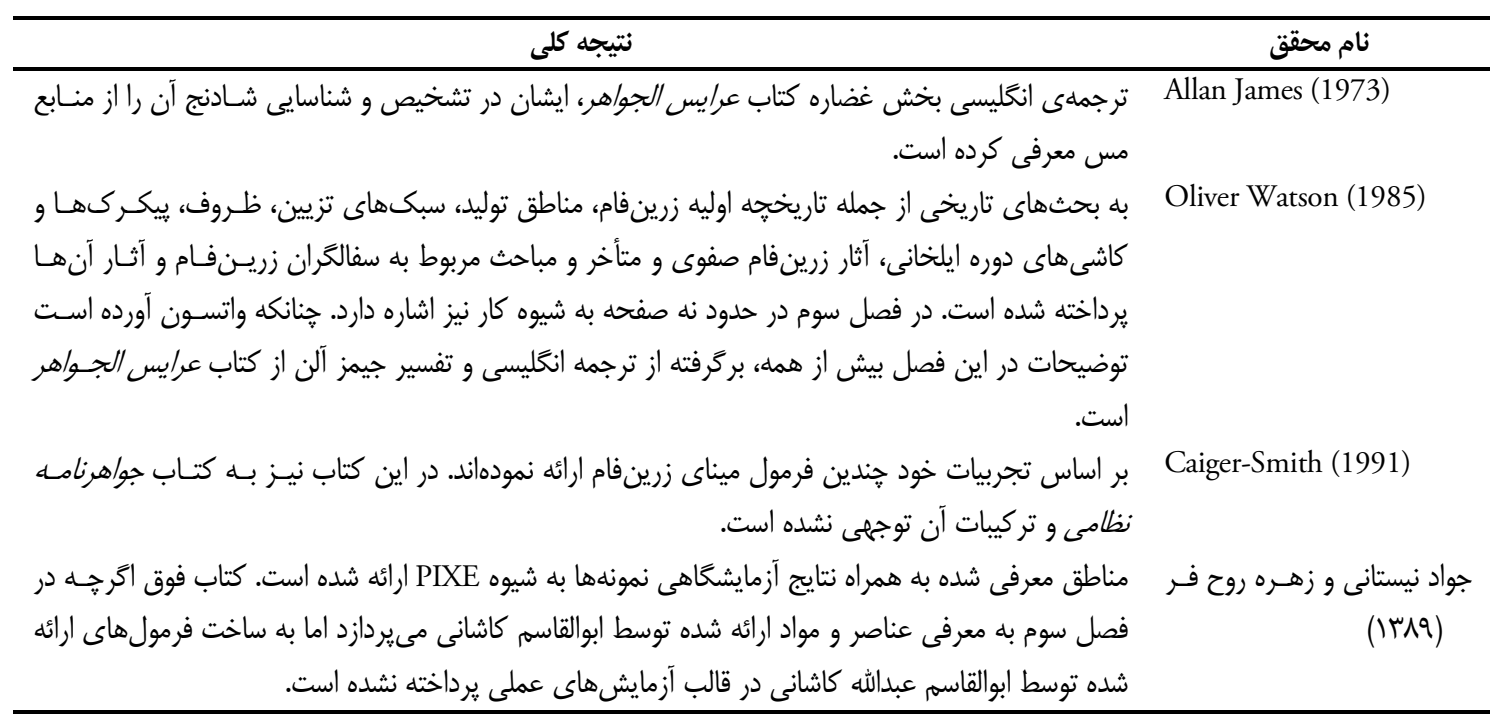


در زمينه ييشينه فناورى نانو به بحث يرداخته و فناورى ميناهاى زرينفـام را توضـيح داده اسـت. وى ضـمن

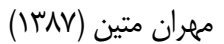

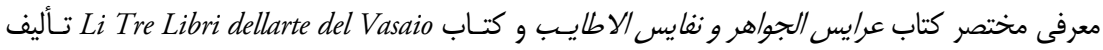

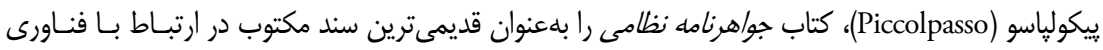

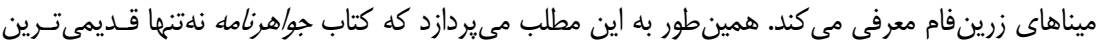

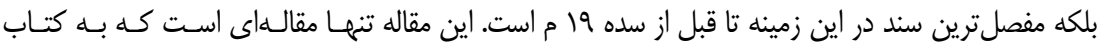

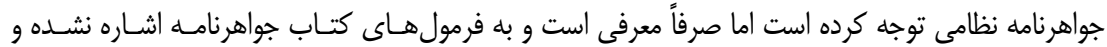

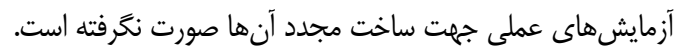

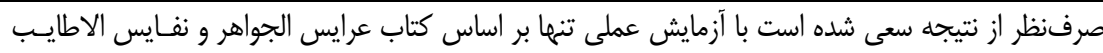

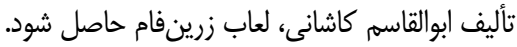
عباس عابد اصـفهانى و يرويـز هلاكويى (هیrس)

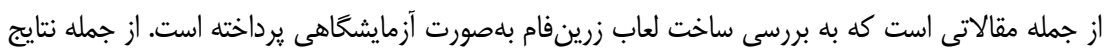

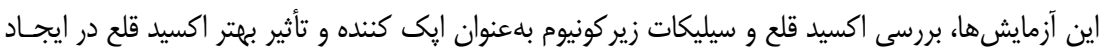
حســين قصـايى، حميدرضـا

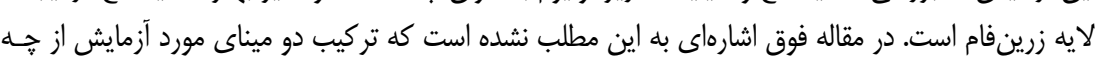

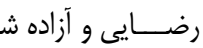

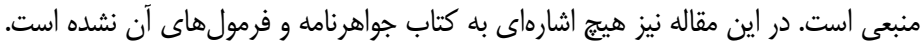

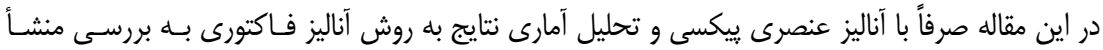

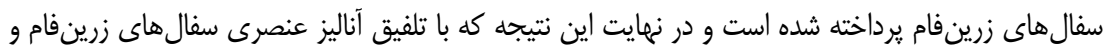

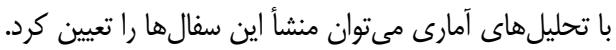

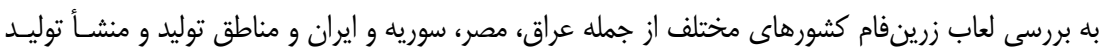

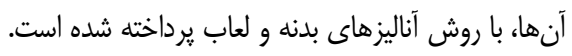

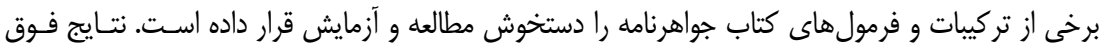
صرفاً بر روى سفال لعابدار انجام گرفته است.

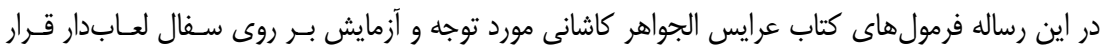

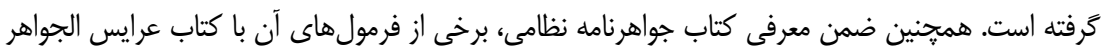

داود آقا على كَل و ديخـران

(I)人D)

Robert Mason (2004)

سيد محمد ميرشفيعى (F) (I ) سيد محمد ميرشفيعى (•qسו) مقايسه تطبيقى شده است.

هاى مينايى، به علت ضخامت يك ميكرونى نامحسـوس

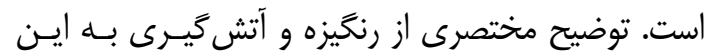
قرار است: خود رنخيزه شامل مخلوطى از تركيبات نقـره و

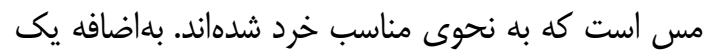

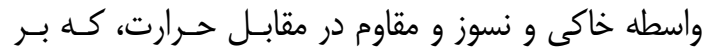

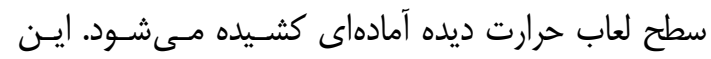

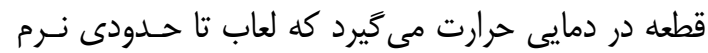

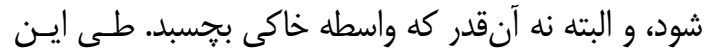

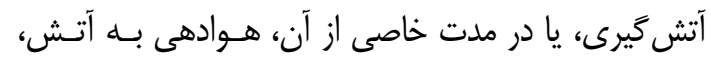
براى ايجاد يك اتمسفر كاهشيافته، بلوسـيله توليـد گَاز

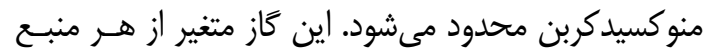

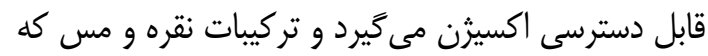

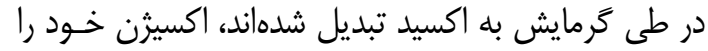

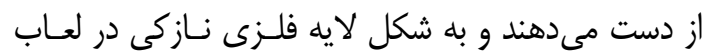

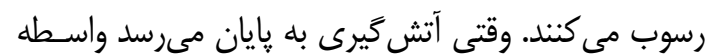

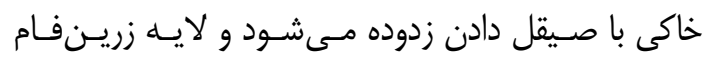

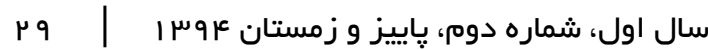

\section{- ت تكنيك زرين -}

به نظر مىرسد تكنيك زرين فام كه تركيبات فلزى، مانند اكسيدهاى نقره، مس يا طلاى حـل شـــه در اسـيد روى

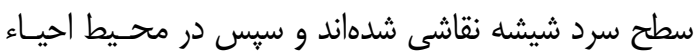

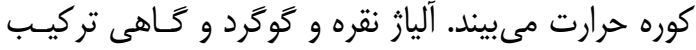

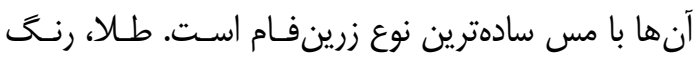
متمايل به قرمز و نقره بلتتهايى رنغى زرد ايجاد مسى كنــد.

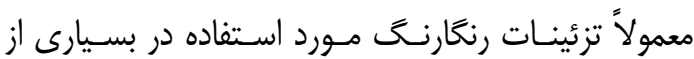
قطعات يافت شده از فسطاط (يايتخت اسلامى مصر مابين

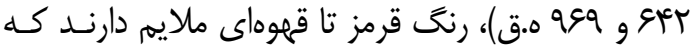

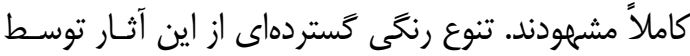
اين تكنيك قابل شناسايىاند (Klain, 1984, p. 56). زرينفـام شـيوه لعـاب روى نقـش اسـت كـه در آن رنخَيزه در يك آتش گيرى ثانويه، در دمايى كمتر از دمـاى اوليه، روى سطح لعاب محكمم و حرارت ديسـداى بــه كـار كرفته مىشود. بههرحال لعاب زرينفام، برخلاف رنخيـزه 
دوددان نهند جنان كه ياد كرده شد آتش مى كنند تـا سـرد

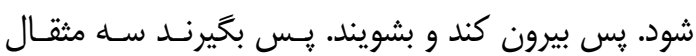

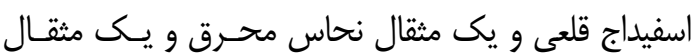

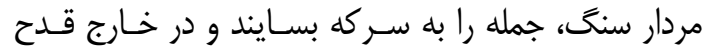

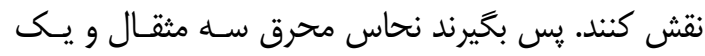
مثقال مرقشيثا و يك مثقال شادنج و يك درم توبال بـرنج

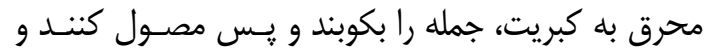

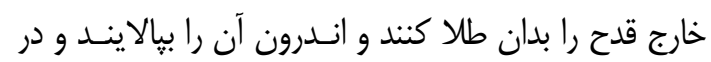

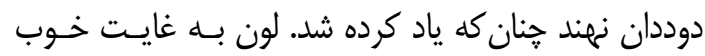
حاصل آيد: لون زرد و لاجورد و نقره رنغ نئ.

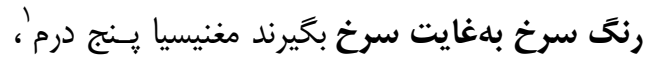

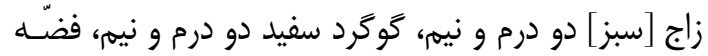

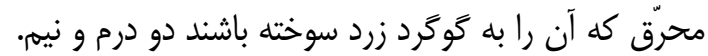

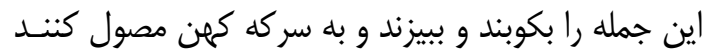

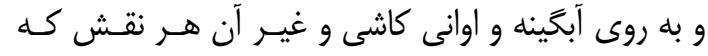

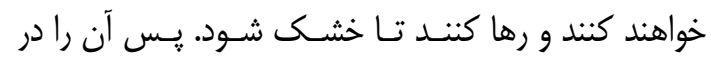

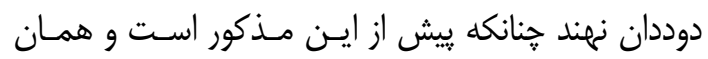

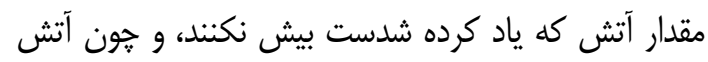

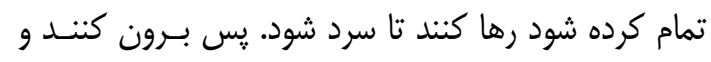
آن را پاكيزه بشويند. لونى به غايت سرخ بد بديدار آمده بود.

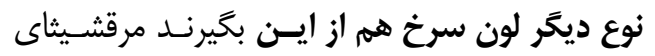

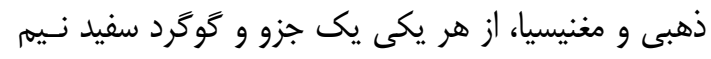

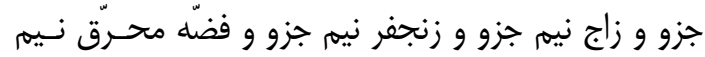

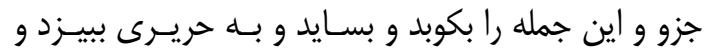

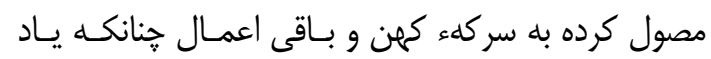
كرده شده است، خون كرده شود لونى بود به غايت سرخ

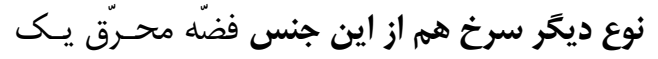

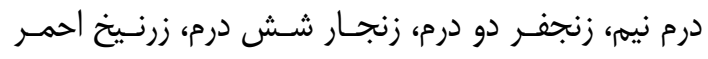

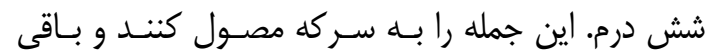
اعمال جنانكه ياد كرده شده است.

\section{صفت لونى كه مانند زر باشد}

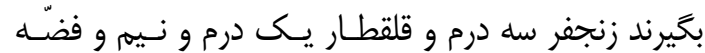

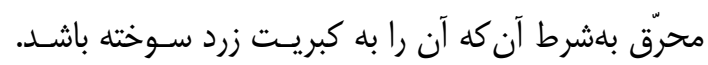

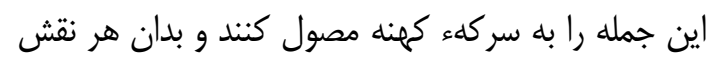
كه خواهند مى كنند و جنانكه ياد كرده شد در دوددان نهند

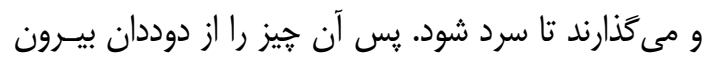

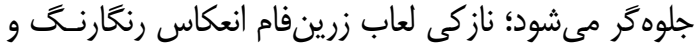

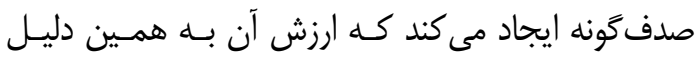

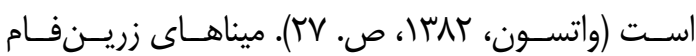

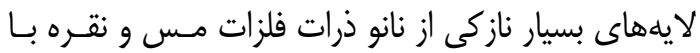
جلا و درخشش فلزى در رنغَهاى مختلف هستند كـه در روى سطح لعاب سراميكهاى سدههاى ميانه و رنسـانس، جهت تزئين آنها اجرا شدهاند. مواد اوليه اصـلى ميناهـاى سئي

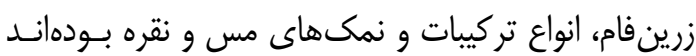

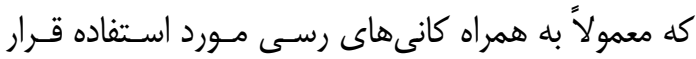

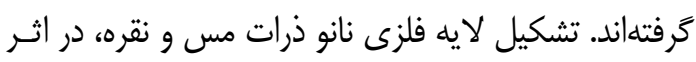

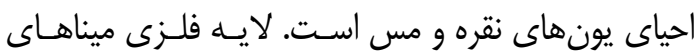

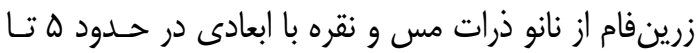

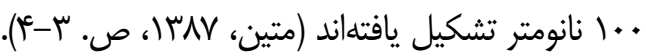

\section{- -

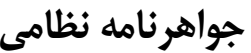

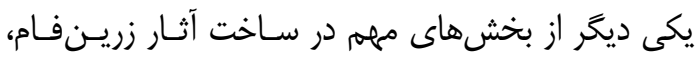
فرمول ساخت جوهر يا ميناى زرينفام است كه ابوالقاسـمم درمام

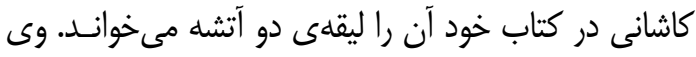

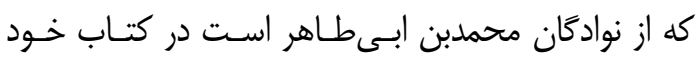

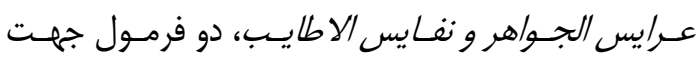
استفاده بر روى سفال ارائه داده است. يكى ديكر از منـابع

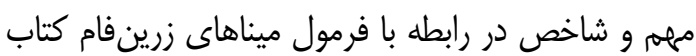
جواهرنامه نظامى است. در كتاب فوق با وجود آنكه بــيش ريش

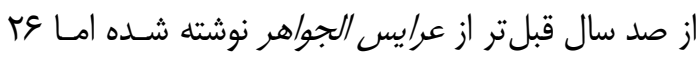

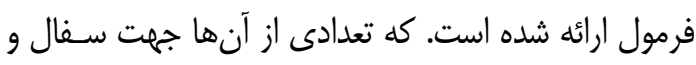
برخى مختص استفاده بر روى شيشه عنوان شده است. در

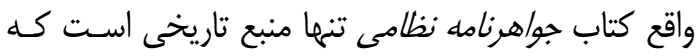

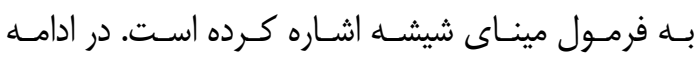
فرمول هاى مربوط به زرينفام شيشه و ذكر شده در كتاب

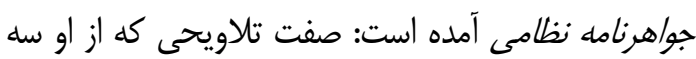
لوبه حاصل آيد بر اقداح آبخينه شامى:

\section{لون زرد و لون لاجورد و لون فضّه}

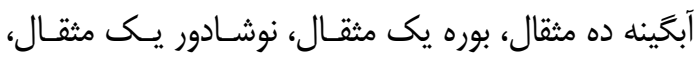

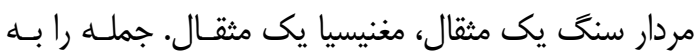

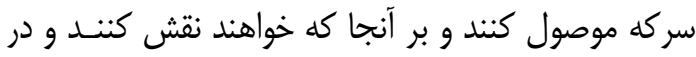

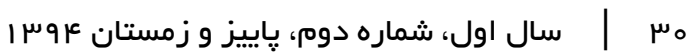


آزمايشكاهى و تجارى به قرار زيـر اسـتفاده شـــ سـولفيد

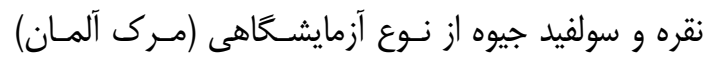

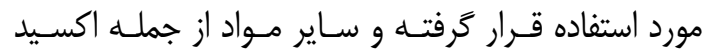

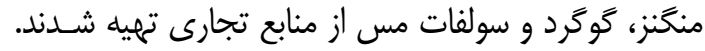

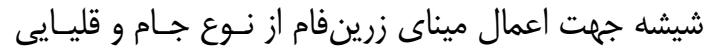

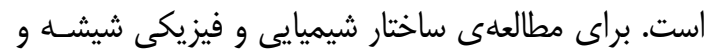

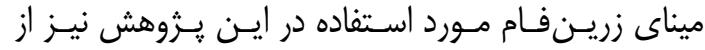

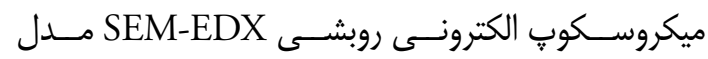
TESCAN (جمهورى جـك) استفاده شـد. كـوره مـورد

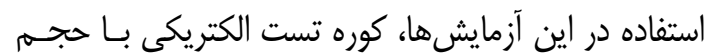

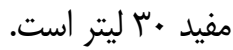

\section{ץ-T- آمادهسازى ميناى زرينفام}

در اين يزوهش از بين هشت فرمول معرفى شده از كتـاب

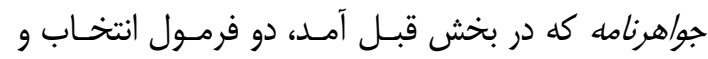
مورد آزمايش قرار كَرفته است. اولين فرمـول منتخــب بـا

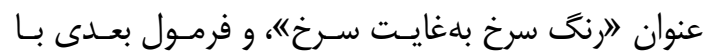
عنوان "صفت لونى كه مانند زر باشده توصيف شده است.

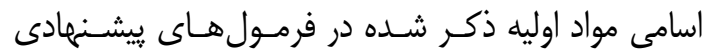

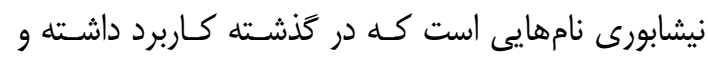

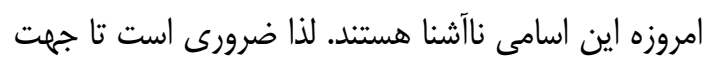
شناخت دقيق ايـن مـواد و تركيبـات ارائهه شــده، معـادل

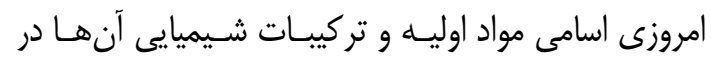

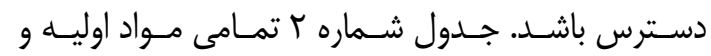
اصطلاحات بهكار رفته با آوانويسى و مشخصـات كـانى و و

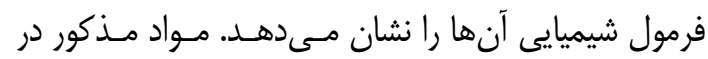

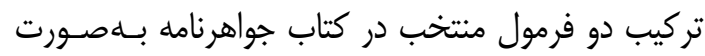
معادل امروزى كه در جدول شماره r آمدهاند براى انجـام

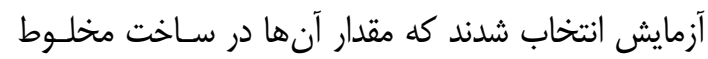
ميناى زرينفام در جدول سا و ع آمده است. يس از وزن كردن تركيب مواد فوق، تمامى آنهـا بـاــا

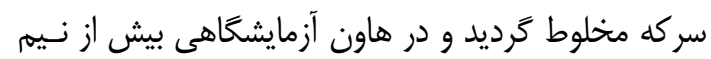

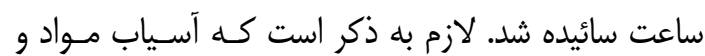

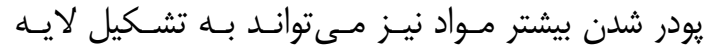

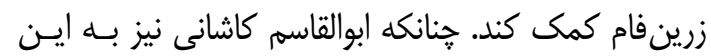
مطلب اشاره دارد: البر صلايه دو شبانهروز سحق كنــــــــا

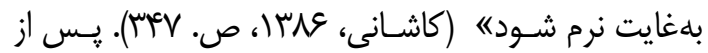

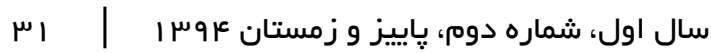

مى گيرند و پإك مى شويند لونى حادث مىشود مثـل لـون

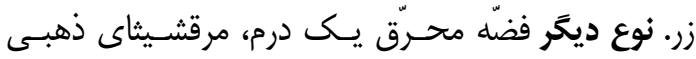

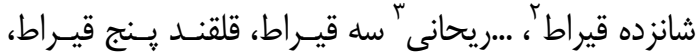

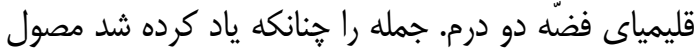

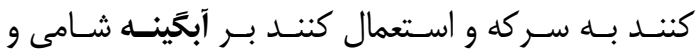
سفالينههاى كاشى و غير آن، مانند زر بيرون آيد.

\section{صفت تلاويح " مثل جزع}

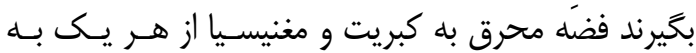
مقدار يك درم و نيه، زنجار دانگى و نيه، قلقند نيم دانگ.

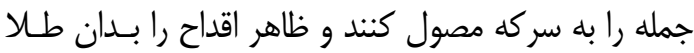

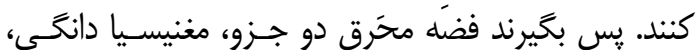

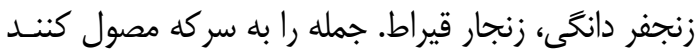

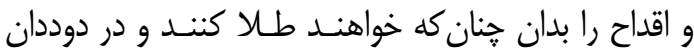

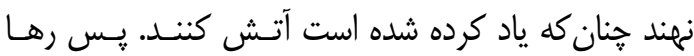

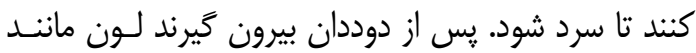

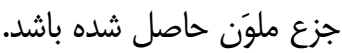

\section{نوعى ديكَر ماند جزع ملوَن}

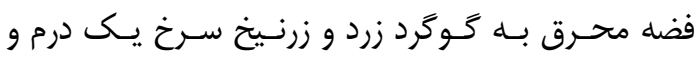

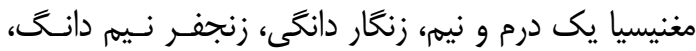

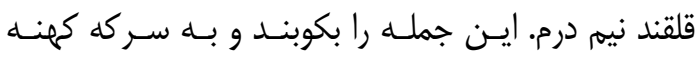

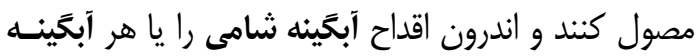
سفيد و شفاف كه باشد بر آن طلا كنند، جُنان كه خواهند.

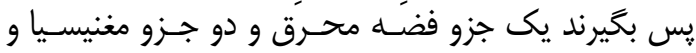

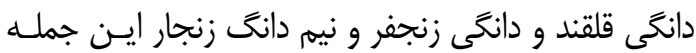

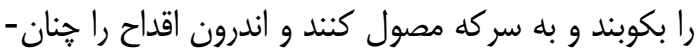

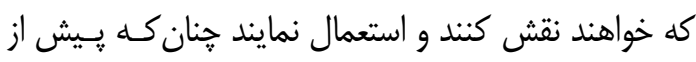

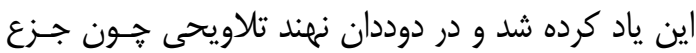

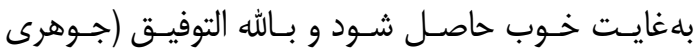

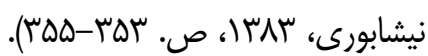

\section{r- r - مواد و روشها} ץ- 1 - مواد و دستخاههاى مورد استفاده در اين يزوهش ابتدا تلاش شد تـا معـادل امـروزى مــواد مذكور در دو فرمـول منتخـب از كتـاب شناسـايى شـوند.

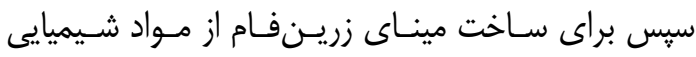


ساعت و نيم نتيجه بهترى را در بر خواهد داشت.

\section{تعداد دفعات دوددهى و شدت احياء}

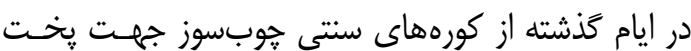
سراميك و همجنين زخت احياء لعـاب زريـنفــام اسـتفاده مىشده است. اين مسئله نيز هم در كتاب عرايس الجواهر

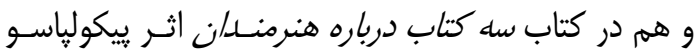

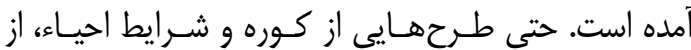

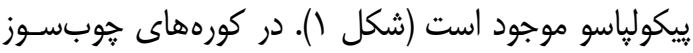

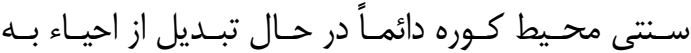
اكسيداسيون و بالعكس است كه اين مطلب خود به يخش

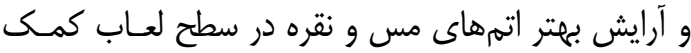
كرده و موجب تشكيل لايه فلـزى مـنظهمتر و دقيـقتـر مى شود. كذشته از طرز تهيهى ميناى زرينفام، طرح كوره هم اهميت زيادى دارد. بييكولٍاسو كَزارش مى كند كله، بنـا

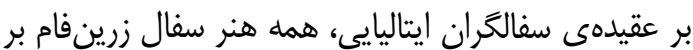
نحوهى ساخت كوره متكى است، تا حدى كه اين كورههـا در اتاقهاى بسته نكَهدارى مى شدند. كنترل درجه حرارت

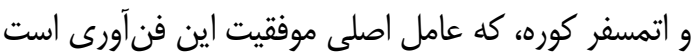
به نوع كوره وابسته بوده است (واتسون، rیז"، ص. זr).

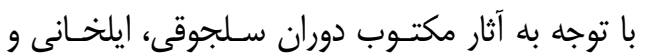

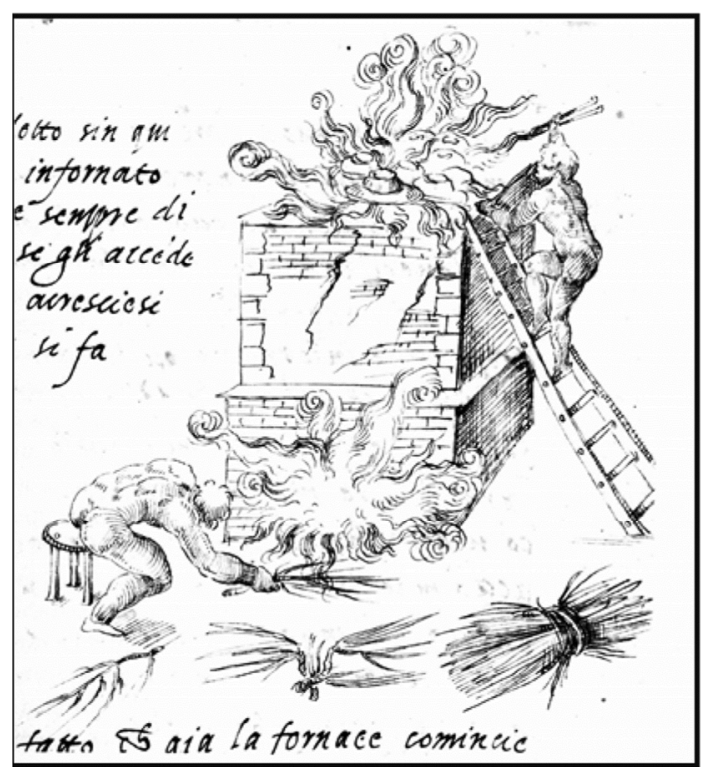

شكل (: طراحى بيكولِاسو، كوره جوب سوز در حال احياء (رادز، rATM

سال اول، شماره دوه، پِاييز و زمستان ع س س
سانتى گراد است. اين دما بستخى مسـتقيم بــه شيشـهـه و

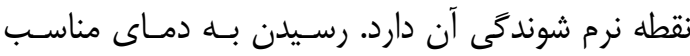

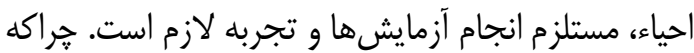
يخت در دماى بالاتر از حد نياز موجب فرو رفتن بيش از

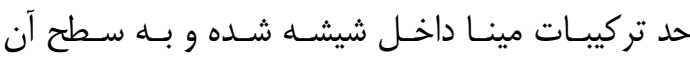

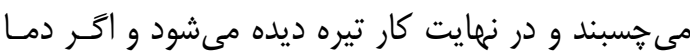

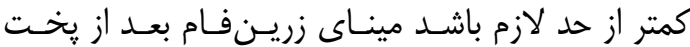

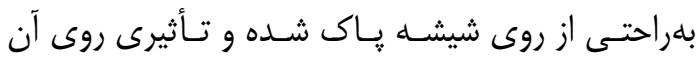

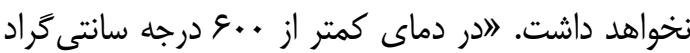
(در كورههاى غير الكتريكى) اجسام نورى از خود منتشـر نمى كنند و در نتيجه داخل كوره تاريك و غيرقابل رؤيت

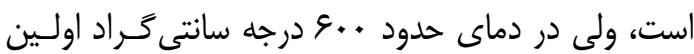
تابشها با طولموجى كه به نظر قرمز تيره مىآيد، منتشر

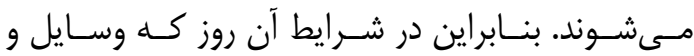

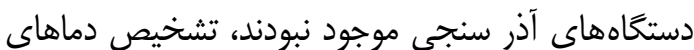

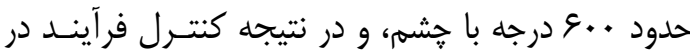

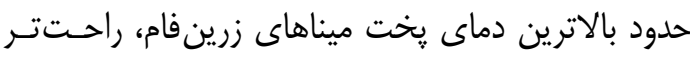

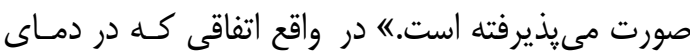
حدود · • ع درجه سانتى گراد مىافتد اين است كه لامكان تعويض بين يونهاى مس ( در مخلوط مواد اوليه زرينفام و يونهاى سديم ( يتاسيم (K) موجود در لعاب يا شيشه به وجود مسى آيسد.

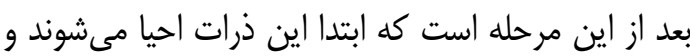

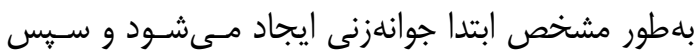

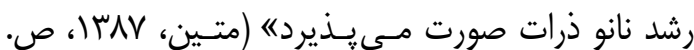

$.(1)-1)^{2}$

\section{مدت احياء}

مورد بعدى در انجام يك احياء موفق كنترل مدت زمـان احياء است. همانطور كه در متن عرايس الجـواهر آمــده

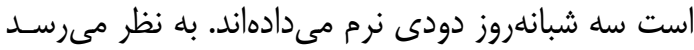

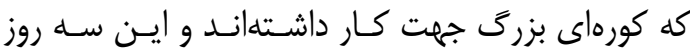
شامل جيدن آثار داخل كوره و دوره سرد شدن آن را نيز شامل مىشود. بههرحال مدت زمان احياء نيز بستگى به بزرگیى و كوجگى كوره دارد. تجربه و نتيجه احياء در كوره تست آزمايش هاى اين يزوهش نشان دهنده اين موضوع

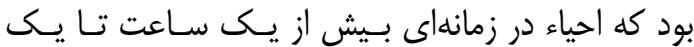


عظيمى از دود سياه از روزنههاى كوره خارج شـود. موقـع

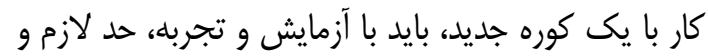

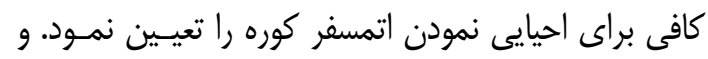

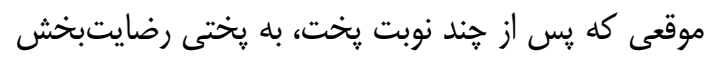

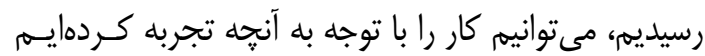

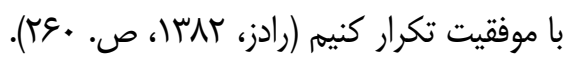

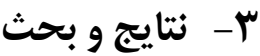

در بخش آزمايشها هر دو ميناى منتخب بر روى شيشـه

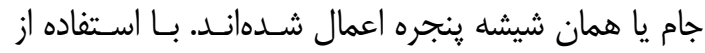

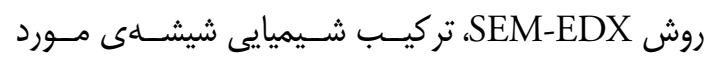

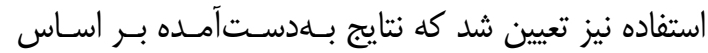

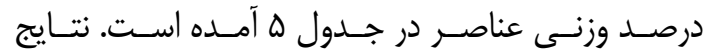

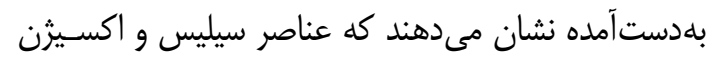
بلهنوان عناصر تشكيل دهندهى تركيب اصلى شـبكهسـاز،

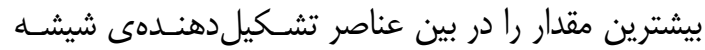
دارا هستند.

پِ از اعمال هر دو ميناى تهيه شده بر روى سـطح

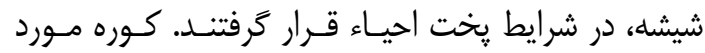

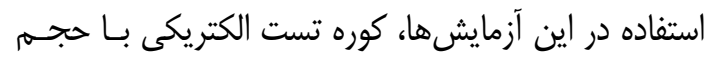

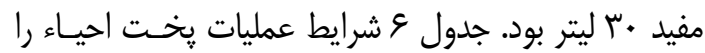
نشان مىدهد. دماى احياء و زمان و دفعات احياء در جدول

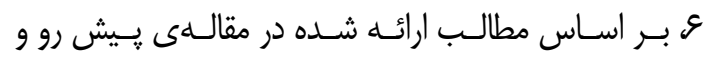
همجنين بر اساس تجربهى كار نغارنده در رابطه با سـاخت ميناى زرين فام بر روى سفال لعابدار، انتخاب شده است.

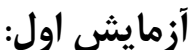

در اين آزمايش فرمـول اول (جـدول r) در شـرايط احيـاء

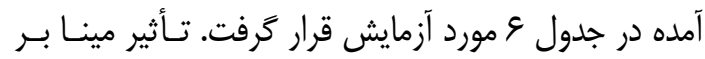
روى شيشه ديده مىشود (شكل r). در اين آزمايش طيف

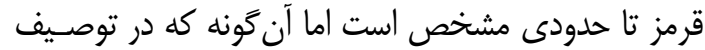
اين تركيب در كتاب جواهرنامه آمده بلهغايت سرخ نيست.
رنسانس ايتاليا، محيط كـوره از ابتــاى قيخـت، احياكنتــه

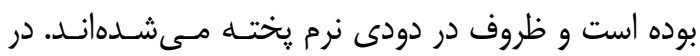
حدود بالاترين دما، شدت احيا افزايش داده مى ندا نده اسـت.

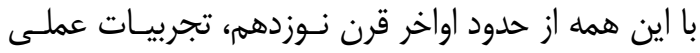

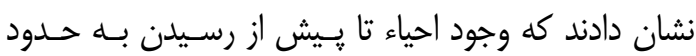

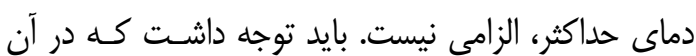

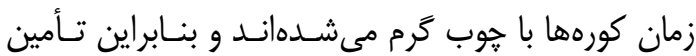

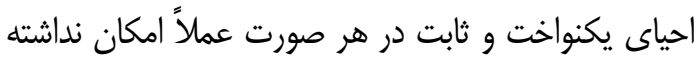

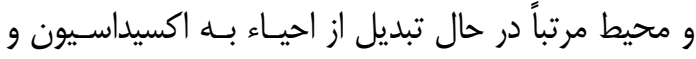

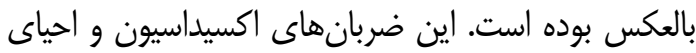
كوره باعث تغييرات مكرر در وضعيت اتسمهــا و در نتيجهـه

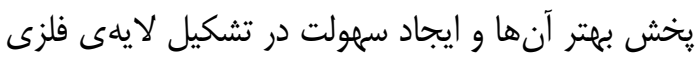

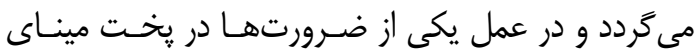

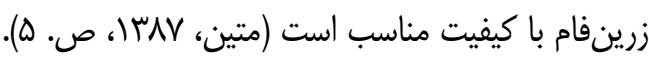

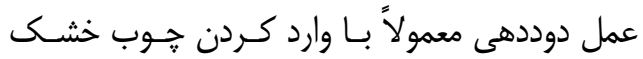
داخل كوره صورت مى گيــدد. در كتـاب عـرايس الجـواهر اشارهاى به نوع جوب، هنگام احيا نشده است. اما در مـورد

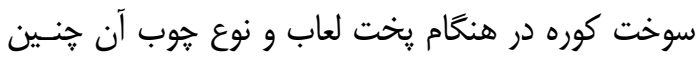

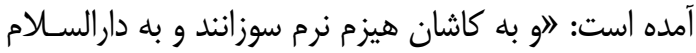

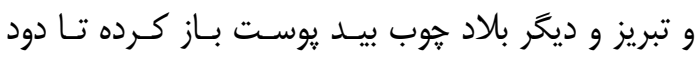

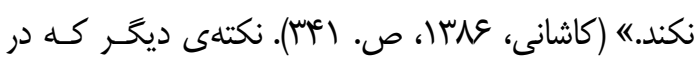

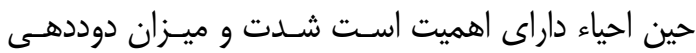

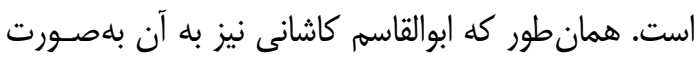

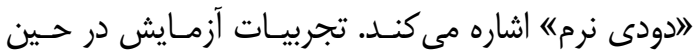
انجام دوددهى نيز نشان داد كه اكر شـدات دوددهـى بـالا

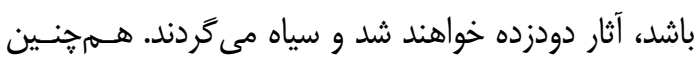

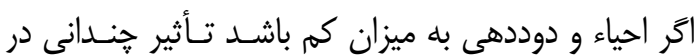
تشكيل و ظهور لايه فلزى نخواهد داشت. شـدت احيـاء و كنترل آن از جملـه مـواردى اسـت كـهـ در تشـكيل لايسه

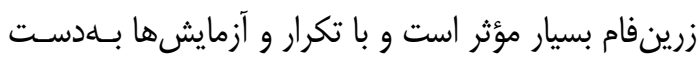

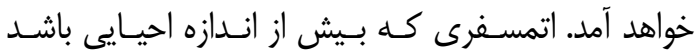

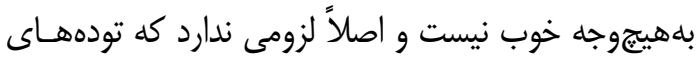

جدول ه: ميزان عناصر شيميايى موجود در شيشه مورد آزمايش

\begin{tabular}{|c|c|c|c|c|c|c|c|c|}
\hline $\mathrm{Na}$ & $\mathrm{Ca}$ & $\mathrm{Mg}$ & $\mathrm{Al}$ & $\mathrm{Si}$ & $\mathrm{Fe}$ & $\mathrm{O}$ & $\mathrm{C}$ & عنصر \\
\hline N/ & $1 / 4$ & $r / \cdots$ & $\cdot / \Delta$ & $M / T$ & $1 / 0$ & $\Delta N / \Delta$ & $N / T$ & مقدار (w\%) \\
\hline
\end{tabular}


دو فصلنامه يزّوهمى باستانسنجى

جدول ؤ شرايط عملياتى تخت احياء

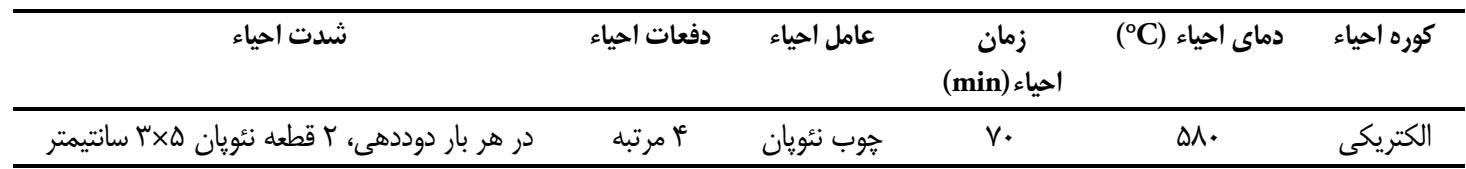

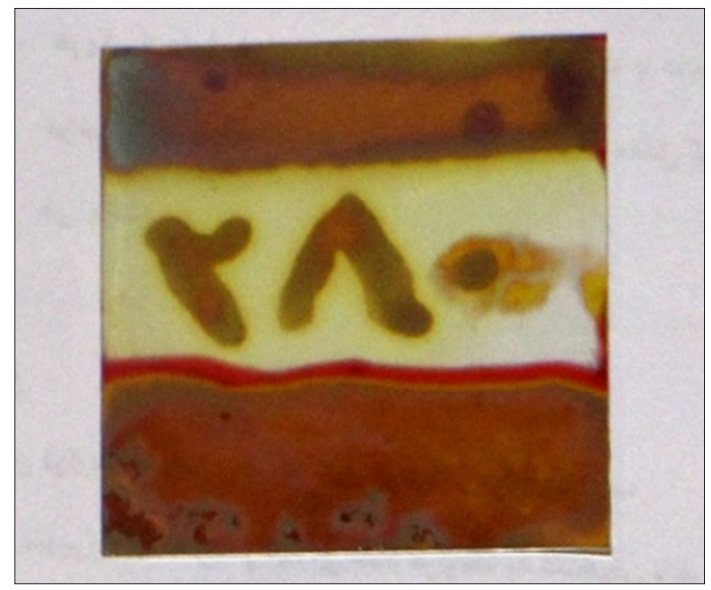

شكل ז: نمونه تست ميناى اول، يس از اتمام يخت احيا، اضافات مينا

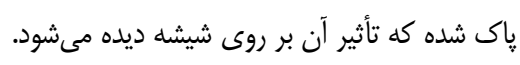

از دلايل اين موضوع مىتوان به تأثير نوع شيشه نيز اشاره

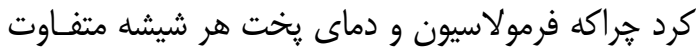

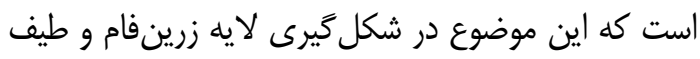
رنكى آن تأثير گذار است.

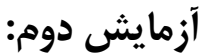

در اين آزمايش فرمول دوم طبق جدول شماره أ ساخته و

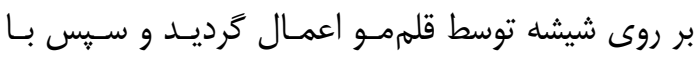

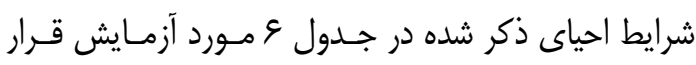

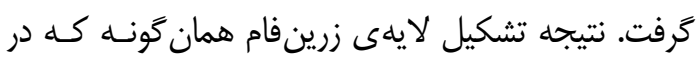

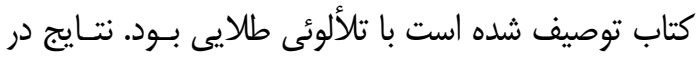
تصاوير شماره تّو أ در زير ارائه شده است.

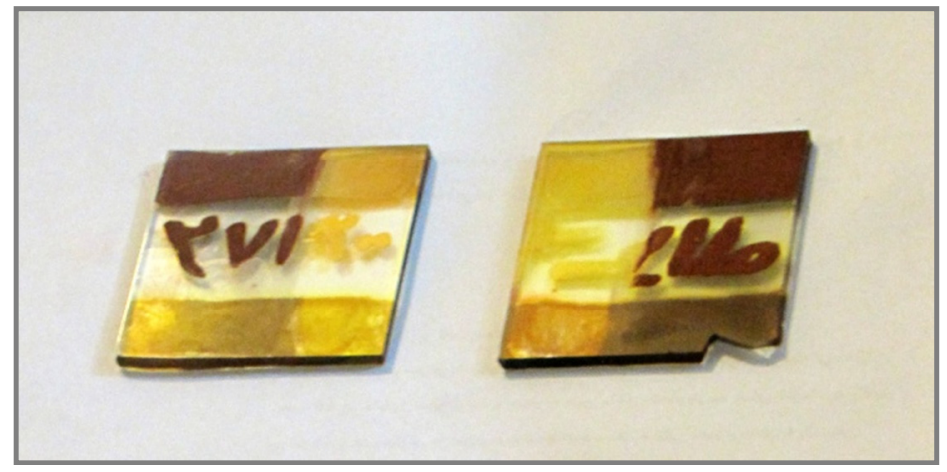

شكل": نمونه آزمون ميناى دوم، پِ از اتمام پِخت احيا، بخشى از مينا پاك شده است كه تأثير آن بر روى شيشه با تالألوئى طلايى ديده مىشود.

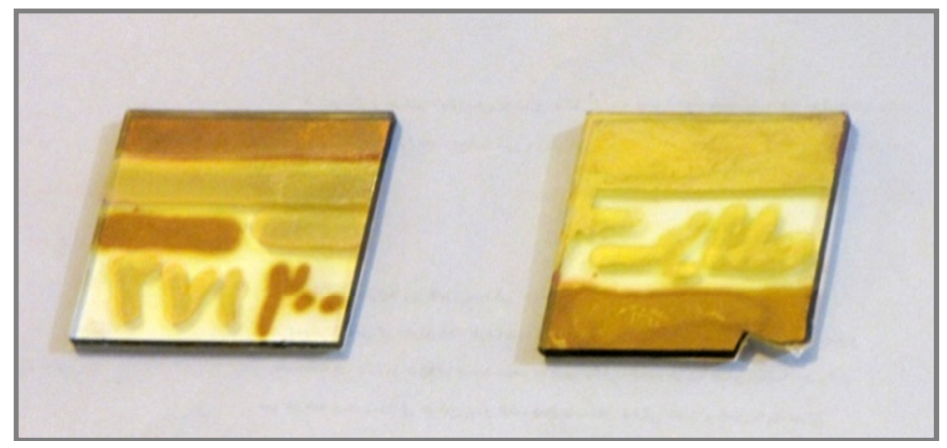

شكل": مينا و اضافهاى تركيبات (خمير كلى) بهطور كامل از سطح شيشه پاك شده است.

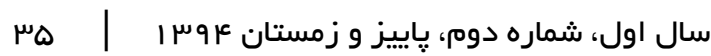


جدول V: ميزان عناصر شيميايى موجود در لايهى ميناى زرينفام (دومين فرمول)

\begin{tabular}{|c|c|c|c|c|c|c|c|}
\hline $\mathrm{Si}$ & $\mathrm{Ag}$ & $\mathrm{Hg}$ & $\mathrm{Fe}$ & $\mathrm{Na}$ & $\mathrm{O}$ & C & عنصر \\
\hline$r /$. & $r / T$ & .10 & $1 /$. & $T / T^{e}$ & $\Delta F / T$ & $T V / D$ & مقدار (w\%) \\
\hline
\end{tabular}

شيشه مورد آزمايش قرار گيرد. از آنجايى كـه در برخى از

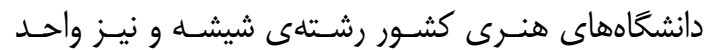
كاركاهى تحت عنوان نقاشى بر روى شيشه ارائه مىشـود،

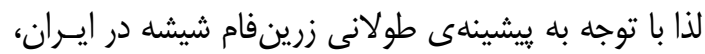
ضرورى است تا اين تكنيك فراموش شــــ آمـوزش داده شود تا ضمن هر خه كاملتر شدن مباحث فنسى و تئسورى

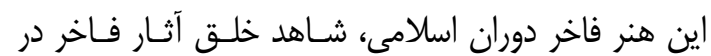

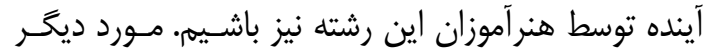

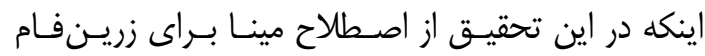
استفاده شده است درحالى كه در رابطه با اصطلاح زرين الصام

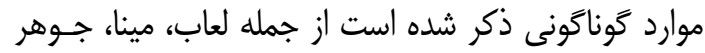

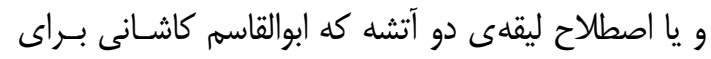

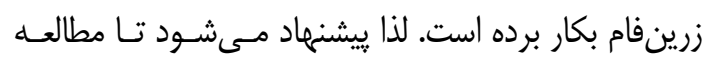

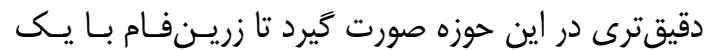
اصطلاح واحد و كاملاً علمى ناميده شود.

\section{تشكر و قدردانى}

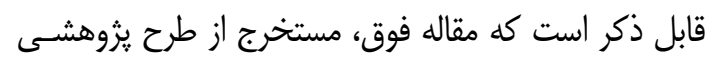

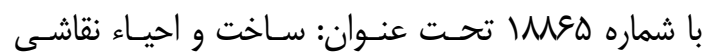

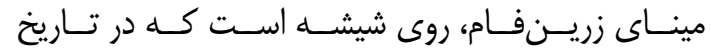

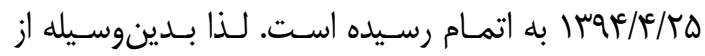

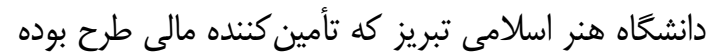

$$
\text { است قدردانى مى گردد. }
$$

\section{يىنوشتها}

1. درم: واحد اندازهگيرى كه برابر يك دهم وزن سكهى

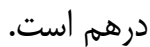

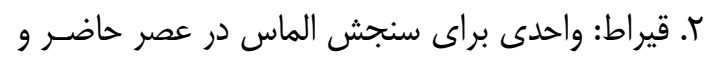

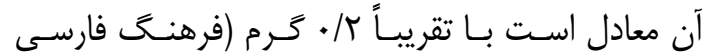

". در متن اصلى جواهر نامه، اسم ماده ياك شده است.

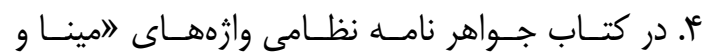

در ادامه ساختار شـيميايى مينـاى دوم مـورد مطالعهـ

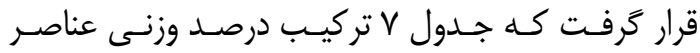
عمدهى موجود در ميناى تشكيل يافته را نشان مىدهد. نتايج حاصل حضور نقره را در ساختار شـيميايى مينـا

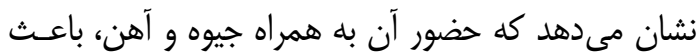

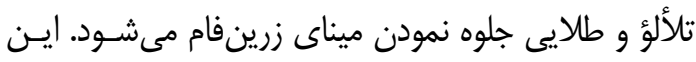

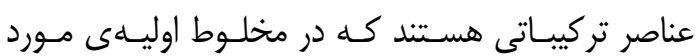
استفاده براى تهيهى ميناى زرينفام (جدول ع) نيـز مـورد

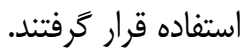

\section{f أنتيجه Fيرى}

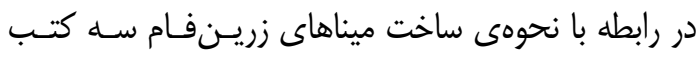
تاريخى جواهرنامه نظامى تـأليف محمــدبن ابـى البركات نيشابورى (قرن و ه.ق) و كتاب عرايس الجواهر و نفايس الاطايب تأليف ابوالقاسم كاشانى (قرن V ه.ق) و كتاب سه ونه

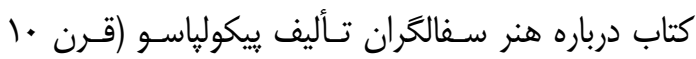
ه.ق) وجود دارد. از بين اين سه كتاب تنهـا در جواهرنامـهـ نظامى به فرمولهاى ميناى شيشه بلهطور مستقيم اشاره و

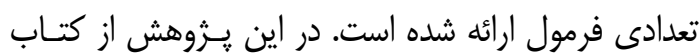

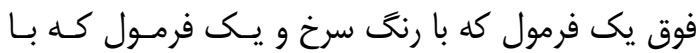

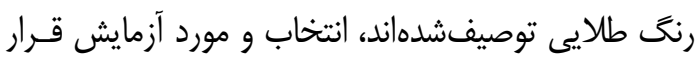

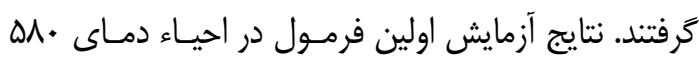

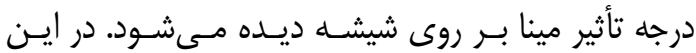
آزمايش طيف قرمز تا حدودى مشخص است اما آنَّونسه

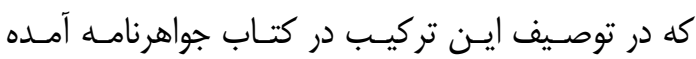

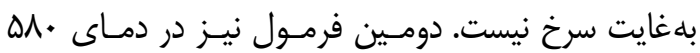

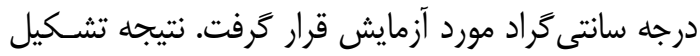

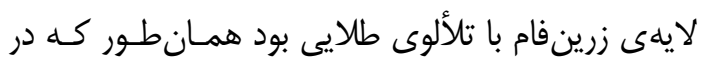

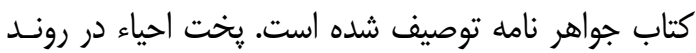
شكل گيرى لايهى زرينفـام از اهميـت بـالايى برخـوردار

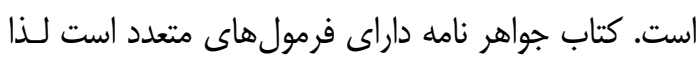

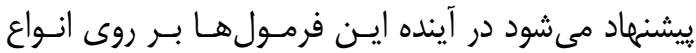


رازى، محمــــ زكريــا. (وعسا). الاســرار. بــهـ كوشـش حسنعلى شيبانى. تهران: دانشعاه تهران.

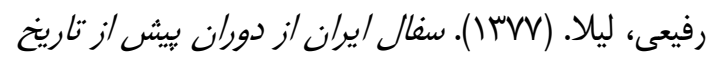
تا عصر حاضر. تهران: يساولى.

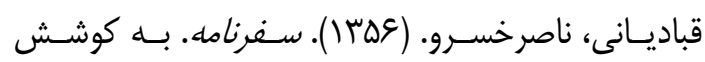
محمد دبير سياقى. خاب دوم، تهران: زواره. قصـايى، حسـين، رضـايى، حميدرضـا، و شـمس، دئ، آزاده.

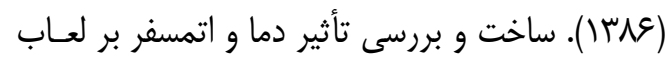

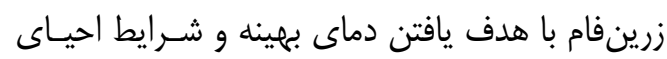
مناسـب. ششـمين كنَــره سـراميك ايـران، تهــران: بزروهشَاه مواد و /نرزى، انجمن سراميك /يران.

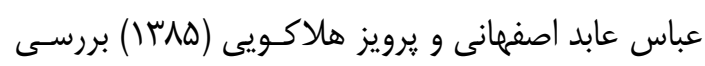

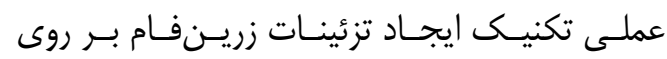
لعابهاى دوران اسلامى، مطالعات هنر /سلامى: ياييز

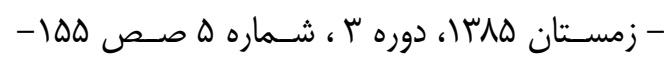
.199

كاشانى، ابوالقاسم عبـداله. (عیىسا). عـر/يس الجـواهر و نقايس الاطايسب. بــه كوشـش ايسرج افشـار. تهــران: انتشارات المعى.

كامبخش فرد، سيفالله. (س^را). سـفال و سـفالكرى در ايران. جاب دوم. تهران: ققنوس.

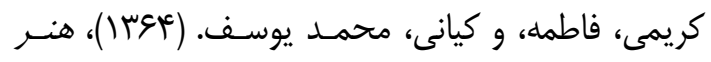
سفالكرى دوره /سلامى /يران. تهران.

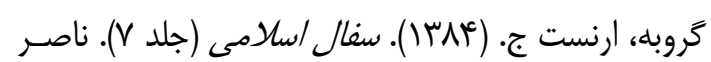
خليلى. تهران: كارنت.

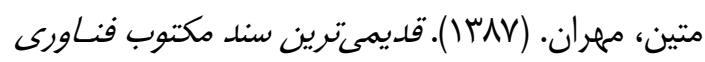

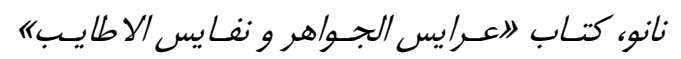
نيست. نخستين همايش فناورىهـاى بـومى ايـران.

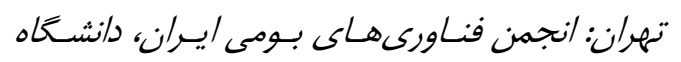
صنعتى شريف. محمدزاده ميانجى، مهناز. (rوس) (1). بررسى سير تساريخى

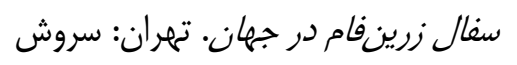
محمدزاده ميانجى، مهنـاز، و قصـايى، حسـين. (•وسار). بررسى عوامل مؤثر بر ساخت لعاب زرينفام با تكيـه

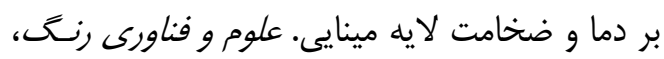

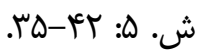
ميرشفيعى، سيد محمد. ( •وسا). بررسـى و احيـاء لعـاب

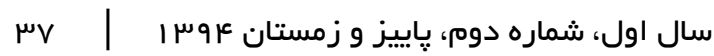

تلاويحاته بر سه نوع از تركيبات و محصولات مختلف دلالت دارد؛ در مفهوم اول، منظور از مينا انواع جواهرات

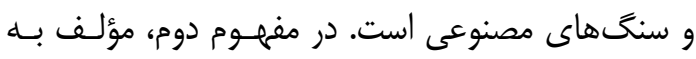

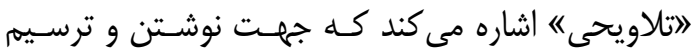

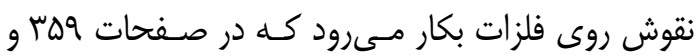

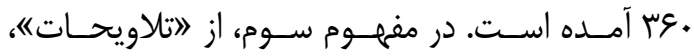

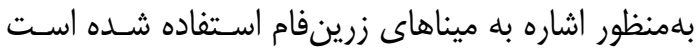
كه شامل تركيباتى مى شود كه در ايـن مقالـه نيـز آمــده

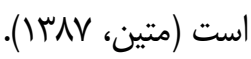

\section{فهرست منابع}

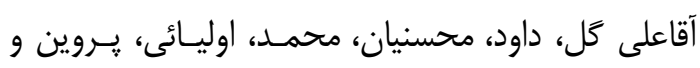

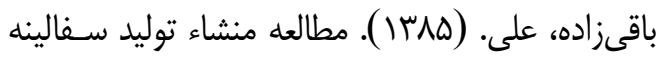
هــاى زريسن فـام ايرانـى بــا اسـتفاده از روش آنـاليز

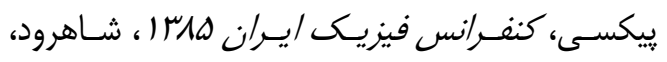
دانشعاه صنعتى شاهرود در دسترس به به آدرس: http://www.civilica.com/Paper-IPC85IPC85_194.html

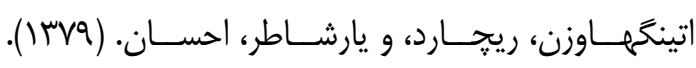

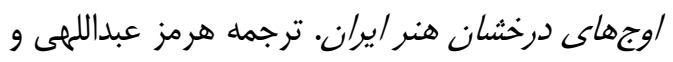
رويين گاكباز. تهران: آكاه.

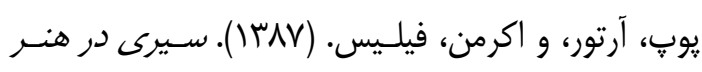

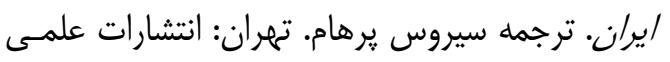

$$
\text { و فرهنگیى. }
$$

يورتر، ونيتيا. (1) (1). كاشىهایى اسلامى. ترجمه مهنـاز شايسته فر. تهران: مطالعات هنر اسلامى.

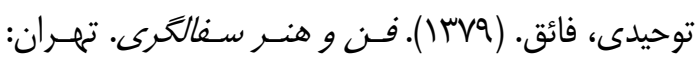
سمت. جوهرى نيشابورى، محمــد بـن ابسى البركـات. (سمبا). جواهر نامه نظامى. به كوشـش ايسرج افشـار. تهـران: ميراث مكتوب.

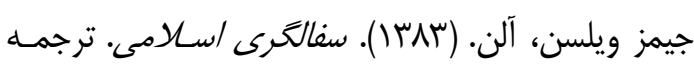
مهناز شايسته فر. تهران: مطالعات هنر اسلامى.

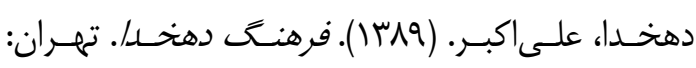

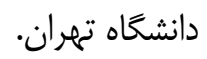

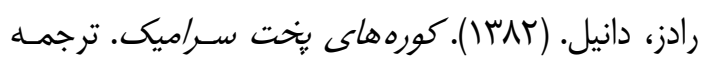
شعبانعلى تشكرى. خاب دوم. تهران: فنى حسينيان. 


$$
\begin{aligned}
& \text { ايرانى بر اساس كتاب جواهر نامـهـ نظـامى. هنرهـاى } \\
& \text { زيبا، ش.•r، د.ا: ه9-هو. }
\end{aligned}
$$

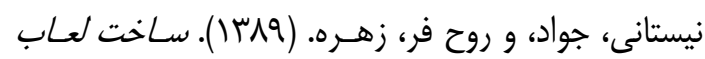

$$
\begin{aligned}
& \text { زرينفام در/يران. تهران: آرمانشهر. }
\end{aligned}
$$

\section{منابع لاتين}

Caiger-Smith, A. (1991). Lustre Ware Technique. London: Herbert Press.

Carboni, S. (2001). Glass of the Sultans [Book]. New York: Metropolitan Museum of Art.

Carboni, S. (2001). Glass from Islamic Lands. London: The Al-Sabah Collection.

James, A. (1973). Abul-Qasims Treatise on Ceramics Iran. London: The British Institute of Persian Studies.

Klain. D. (1984). The History of Glass [Book]. London: Little Brownand Company.

Kroger, J. (1995). Nishapur glass of the early islamic period [Book]. New York: Metropolitan Museum of Art.

Lamm, C. J., \& Hannibal, A. (1935). Glass from Iran in the National Museum. CE Fritze.

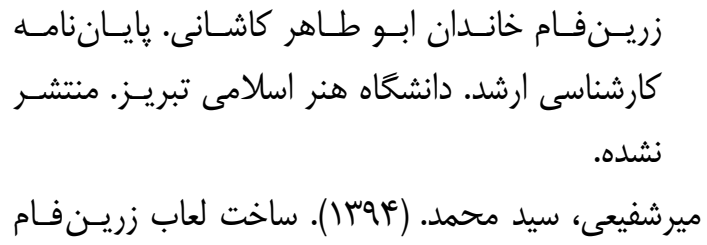

Mason, R. B. (2004). Sbine like the sun: Lustre-Painted and Associated Pottery from the Medieval Middle east (Vol. 12). Mazda Pub.

Mirshafiei, M., \& Bagherzadeh Kasiri, M,. (2015). The Study of Luster Glaze Synthesis on the Basis of the First Formula in Book "Javaher Name-ye-Nezami”. J. Color. Sci. Tech. JCST-2107-2015-1597.

Newby, M. (2000). Glass of four millennia. Ashmolean Museum.

Piccolpasso, C., Lightbown, R. W., \& CaigerSmith, A. (1980). The three books of the potter's art (I tre libri dell'arte del vasaio): a facsimile of the manuscript in the Victoria and Albert Museum.

Tait, H. (2012). 5000 Years of Glass [Book]. London: British Museum.

Watson, O. (1985). Persian Lustre ware. London: Boston. 